\title{
Magnetic Resonance-Guided High-Intensity Focused Ultrasound (MR-HIFU): Technical Background and Overview of Current Clinical Applications (Part 1)
}

\section{Magnetresonanz-gesteuerter hochintensiver fokussierter Ultraschall (MR-HIFU): Technische Aspekte und Überblick über die etablierten Applikationen (Teil 1)}

Authors

Florian Siedek, Sin Yuin Yeo, Edwin Heijman, Olga Grinstein, Grischa Bratke, Carola Heneweer, Michael Puesken, Thorsten Persigehl, David Maintz, Holger Grüll

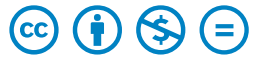

Affiliation

Institute of Diagnostic and Interventional Radiology, University Hospital of Cologne, Germany

Key words

HIIFU, interventional procedures, ablation procedures, hyperthermia, uterine fibroids, pain palliation

received 23.05 .2018

accepted 24.11.2018

Bibliography

DOI https://doi.org/10.1055/a-0817-5645

Published online: 10.1.2019

Fortschr Röntgenstr 2019; 191: 522-530

(c) Georg Thieme Verlag KG, Stuttgart · New York

ISSN 1438-9029

Correspondence

Prof. Holger Grüll

Radiology, University Hospital of Cologne, Kerpener Str. 62,

50937 Cologne, Germany

Tel.: ++49/221/47882035

holger.gruell@uk-koeln.de

\section{ZUSAMMENFASSUNG}

Hintergrund Der extrakorporale hochintensive fokussierte Ultraschall (HIFU) ist ein vielversprechendes Verfahren zur nichtinvasiven Thermoablation gutartigen und bösartigen Gewebes. Derzeitige HIFU-Therapien nutzen Ultraschall (US-HIFU) oder MRT (MR-HIFU) zur Bildsteuerung mit der Möglichkeit zur integrierten Therapieplanung, Echtzeit-Therapiekontrolle (räumliche Orientierung und Temperatursteuerung) und Therapieevaluation.

Methode Dieser Übersichtsartikel basiert auf Publikationen aus Fachzeitschriften, die die thermale Ablation mittels HIFU thematisieren, und beinhaltet zudem eigene klinische Ergebnisse. Es wird ein kurzer Überblick über die häufigsten CEzertifizierten klinischen Applikationen für MR-HIFU gegeben.
Ergebnisse Im Laufe des letzten Jahrzehnts erhielten zahlreiche HIFU-basierte Applikationen die Zulassung in diversen Ländern. Im Speziellen ist MR-HIFU nun zugelassen für die Therapie von Uterusmyomen, Linderung von Knochenschmerzen, der Ablation der Prostata und die Therapie des essenziellen Tremors als erste neurologische Applikationsform.

Schlussfolgerung MR-HIFU ist eine patientenfreundliche, nichtinvasive Methode zur Thermoablation, welche mittlerweile für mehrere klinische Applikationen zugelassen wurde. Insgesamt bestätigen die bisherigen klinischen Daten die Wirksamkeit und Sicherheit der Therapie sowie die Kosteneffizienz der Methode.

\section{Kernaussagen:}

- HIFU stellt eine vielversprechende Technik zur nichtinvasiven Thermoablation von Gewebe dar.

- HIFU wird üblicherweise unter Bildkontrolle mittels Ultraschall (US-HIFU) oder MRT (MR-HIFU) durchgeführt.

- Die bevorzugte Bildkontrolle (US-HIFU vs. MR-HIFU) hängt von der geplanten Applikation ab.

- MRT bietet einen höheren Weichteilkontrast zur Therapieplanung, eine nahezu in Echtzeit und nichtinvasiv erfolgende Temperaturkontrolle und eine postinterventionelle Therapieevaluation.

- MR-HIFU ist CE-zertifiziert für die Therapie von Uterusmyomen, Linderung von Knochenschmerzen, Ablation der Prostata und Therapie des essenziellen Tremors.

\section{ABSTRACT}

Background Extracorporeal high-intensity focused ultrasound (HIFU) is a promising method for the noninvasive thermal ablation of benign and malignant tissue. Current HIFU treatments are performed under ultrasound (US-HIFU) or magnetic resonance (MR-HIFU) image guidance offering integrated therapy planning, real-time control (spatial and temperature guidance) and evaluation.

Methods This review is based on publications in peer-reviewed journals addressing thermal ablation using HIFU and includes our own clinical results as well. The technical background of HIFU is explained with an emphasis on MR-HIFU 
applications. A brief overview of the most commonly performed CE-approved clinical applications for MR-HIFU is given.

Results Over the last decade, several HIFU-based applications have received clinical approval in various countries. In particular, MR-HIFU is now approved for the clinical treatment of uterine fibroids, palliation of bone pain, ablation of the prostate and treatment of essential tremor as a first neurological application.

Conclusion MR-HIFU is a patient-friendly noninvasive method for thermal ablation which has received clinical approval for several applications. Overall, clinical data demonstrate treatment efficacy, safety and cost efficiency.

\section{Key Points:}

- HIFU is a promising technique for noninvasive thermal ablation of tissue.
- HIFU is typically performed under image guidance using either diagnostic ultrasound (US-HIFU) or MRI (MR-HIFU).

- The preferred image guidance modality depends on the application.

- MR guidance offers improved soft-tissue contrast for treatment planning, near real-time and noninvasive temperature monitoring and post-interventional therapy evaluation.

- MR-HIFU is CE-approved for treatment of uterine fibroids, alleviation of bone pain, prostate tissue ablation and treatment of essential tremor.

\section{Citation Format}

- Siedek F, Yeo S, Heijman E et al. Magnetic ResonanceGuided High-Intensity Focused Ultrasound (MR-HIFU): Technical Background and Overview of Current Clinical Applications (Part 1). Fortschr Röntgenstr 2019; 191: 522530

\section{Introduction}

Over the past years, radiological imaging methods such as MRI, US and CT/X-ray have become an integral part of therapeutic interventions such as percutaneous and transarterial procedures to treat vascular and oncological diseases. Imaging allows treatment planning, provides spatial guidance to reach the targeted tissue and facilitates real-time monitoring of the intervention itself, thus ensuring increased safety and improved outcome. Furthermore, treatment can be evaluated in the same session using appropriate imaging protocols thereby providing a prognostic readout for efficacy.

Thermal ablation of tumors or metastases, for example, in the liver is currently performed with minimally invasive procedures under X-ray or CT guidance using percutaneous radiofrequency or microwave applicators that are inserted into the tumor. Yet, the above methods suffer from poor temperature control and insufficient target coverage especially for larger or irregular-shaped tumors. Furthermore, proximity to crucial structures sometimes prohibits insertion of the probe. A promising noninvasive alternative is high-intensity focused ultrasound (HIFU). Ultrasound presents a mechanical wave that can be focused inside the patient on one spot, where absorption and subsequent energy dissipation cause rapid and focal heating of the target tissue. Temperatures over $55^{\circ} \mathrm{C}$ basically induce coagulative necrosis instantaneously with sharp margins between treated and healthy tissue. HIFU can therefore be considered as a thermal knife, however without having to perform open surgery and to remove the tissue. Current HIFU treatments are performed under either ultrasound (US-HIFU) or magnetic resonance (MR-HIFU) imaging guidance, thus offering integrated therapy planning, real-time control (spatial and temperature guidance) and evaluation. The choice of imaging method depends on the exact application and treatment scheme. This review explains the underlying principles of HIFU therapy and presents an overview of the established clinical applications (part 1), while emerging applications that are in a translational or early clinical phase will be reviewed in a future second part (MR-Guided High-Intensity Focused Ultrasound (MR-HIFU): Overview of Emerging Applications (Part 2)).

\section{Principles}

The biological effect of ultrasound was first described by Wood et al. in 1927 upon noticing the detrimental effects of high-intensity ultrasound on animals [1]. Lynn et al. succeeded in focusing high-intensity ultrasound and recognized its thermodestructive potency when applied to an ex vivo tissue sample as well as in vivo when targeting the brain transcranially in cats and dogs [2]. Fry et al. were able to produce focal lesions within the central nervous system in several animal experiments after the skull was removed to avoid extensive heating of the bone surface [3]. Nonetheless, the clinical application of HIFU remained unsuccessful largely due to the lack of heating control and spatial targeting.

For the latter, HIFU was combined early on with diagnostic ultrasound B-mode imaging for improved spatial targeting. Combining HIFU with MR (MR-HIFU) imaging presented a challenge as the transducer needs to be MR-compatible and was first realized by Hynynen et al. [4]. The soft-tissue contrast of MRI and its ability for noninvasive temperature monitoring strongly improved procedure planning, and targeting of the focus spot, which contributed to the safety and efficacy of the procedure and paved the way to broader clinical application of MR-HIFU.

For HIFU ablation, typically frequencies in the range of $0.8-$ $4 \mathrm{MHz}$ are employed with intensities between $400-10000 \mathrm{~W} / \mathrm{cm}^{2}$ ( $\mathrm{I}_{T A}$ - time-averaged intensity) and pressure amplitudes of up to $10 \mathrm{MPa}$ [5], depending on the particular application. In contrast to HIFU, conventional diagnostic ultrasound usually uses a frequency spectrum between 2 and $15 \mathrm{MHz}$, intensities between 0.004 and $7.5 \mathrm{~W} / \mathrm{cm}^{2}$ (ISPTA - spatial peak temporal average intensity) and pressure amplitudes of up to $5.5 \mathrm{MPa}$ depending on the mode being used with the lowest values in $\mathrm{B}$-mode and the highest values in Doppler mode [6]. 
In contrast to diagnostic ultrasound transducers emitting parallel or divergent ultrasonic pressure waves, HIFU transducers typically have a concave shape to focus the waves on one spot. The high intensity in combination with ultrasound absorption within the focus spot leads to a sudden and localized rise in temperature. Heating of tissue to temperatures above $55^{\circ} \mathrm{C}$ induces coagulation necrosis within seconds. The exact size of the focus spot depends on the transducer geometry such as aperture and focal length as well as frequency and has typical dimensions of a few millimeters with respect to the diameter and length. Displacing the transducer for repeated sonication or using a phased array transducer with the ability for electronic beam steering allows ablation of larger volumes [7]. The boundary between viable and ablated tissue consists of only a few cell layers. Ablation efficacy can be assessed directly after the procedure by measuring the non-perfused volume (NPV) using contrast-enhanced ultrasound or MR imaging.

Before a HIFU procedure can be performed, acoustic access to the targeted lesion needs to be ensured, with proximity to gasfilled intestines or reflecting structures such as arteriosclerosis (calcifications), bone, lung or foreign matter being contraindications as they may lead to scattering and reflections of the ultrasound waves with excessive heating of the surrounding tissue as a consequence. Proper patient selection and preparation are therefore strictly required.

Ultrasound guidance of HIFU procedures allows real-time visualization of tissue ablation showing an emerging hyperecho during and after ablation and furthermore provides continuous information about the acoustic beam path and potential obstructions. However, diagnostic ultrasound cannot obtain precise enough temperature information and therefore gives no readout of the achieved absolute temperature or the thermal dose that is deposited in the target tissue. Consequently, adaptive heating strategies with e. g. a power feedback or longer heating times are lacking, which may lead to incomplete ablation especially in areas where perfusion causes faster heat dissipation or near large vessels. MR-HIFU allows planning of sonication based on MR images with fine anatomic detail and high intrinsic soft-tissue contrast. Furthermore, MR-thermometry provides a near real-time temperature map during sonication to track the heating pattern in the focus spot and surrounding tissue which can be used as a feedback to the HIFU transducer ( $\triangleright$ Fig. 1). The closed-loop feedback ensures deposition of a thermal dose sufficient to cause coagulative necrosis across the entire targeted area. Furthermore, the temperature feedback is a key factor in hyperthermia applications, where temperatures of approximately $42^{\circ} \mathrm{C}$ need to be maintained over a prolonged period of time.

The most frequently used clinical systems around the world are the US-HIFU "JC" developed by HAIFU (Chongqing, China) and the MR-HIFU “ExAblate" by InSightec (Haifa, Israel) and "Sonalleve" by Profound Medical (Mississauga, Canada). Additionally, several other HIFU systems from various companies exist or are under development for dedicated applications. Established applications for MR-HIFU and US-HIFU are accounted for licensed procedures under EU regulations (FDA approval, CE-certified) with an overview provided in $>$ Table 1 .
For this review we concentrated on the current status of MR-HIFU as well as a few selected potential future applications mostly related to oncology.

\section{Established applications}

\section{Uterine fibroids}

Symptomatic uterine fibroids are found in $20-40 \%$ of all women of childbearing age, causing dysfunctional uterine bleeding, infertility or mass effects on the bladder, intestines or nerves. Classical treatment schemes comprise medicamentous as well as operative (hysterectomy, myomectomy) or interventional therapies (UAE, HIFU). The noninvasive treatment of uterine fibroids using HIFU is increasingly used in equipped centers as it is an organ-preserving, partly outpatient method with low complication rates and fast recovery. A typical MR-HIFU treatment comprises three steps with an MRI prescan for delineation of the uterine fibroids and subsequent HIFU treatment planning ( $\triangleright$ Fig. 2a), the HIFU treatment as such ( $\triangleright$ Fig. $\mathbf{2 b}$ ), and a contrast-enhanced MR post-treatment scan to evaluate the treated volume ( $\nabla$ Fig. $2 c)$. The latter is typically congruent with the tissue in which a high enough thermal dose was achieved to induce thermal necrosis ( $\mathbf{F i g . 2 b}$ ) and correlates to the non-perfused volume (NPV) observed in contrast-enhanced MR scans ( $>$ Fig. 2c). HIFU allows fast treatment of even large fibroid volumes of up to $500 \mathrm{ml}$ with approximately $240 \mathrm{ml}$ being the average volume [8]. A high NPV is of clinical importance as the reduction of symptoms correlates with increasing NPV ratios [9]. Thus, the NPV is considered to be a measure of technical success with newer MR-HIFU studies achieving NPV ratios of $60-90 \%$ [10].

The indication for HIFU treatment must be well considered as a good selection of patients leads to a higher success rate with lower complication rates.

In order to determine if a patient qualifies for a MR-HIFU therapy, T2-weighted and dynamic contrast-enhanced T1-weighted MR images are acquired to assess the size, quantity, location, signal intensity on T2-weighted images, and perfusion of the fibroids. The assessment of T2-weighted images is of clinical importance as fibroids with a higher signal intensity relative to skeletal muscle, also known as Funaki Type III fibroids, are more resistant to heating and generally excluded from MR-HIFU [11]. In addition, a recent study has shown that the presence of a peripheral rim with a high signal intensity around the fibroids on T2-weighted images, which could be associated with dilated veins, lymphatic vessels, and/or edema, significantly lowered the therapeutic response to MR-HIFU [12].

Exclusion criteria can include the presence of organs such as a voided bladder, intestines or nerves in the beam path. Preparations have to be made accordingly such as bladder-filling, manipulation of the intestines and the uterus, fasting or enema. Contraindications are suspicion of malignancy, pregnancy, an acute inflammatory process, pedunculated subserosal fibroids in addition to the general HIFU and MRI contraindications [13]. Uterine fibroids with a diameter greater than $10 \mathrm{~cm}$, more than 5 myomas, large scars in the acoustic window, e.g. after a c-section, and myomas in the 


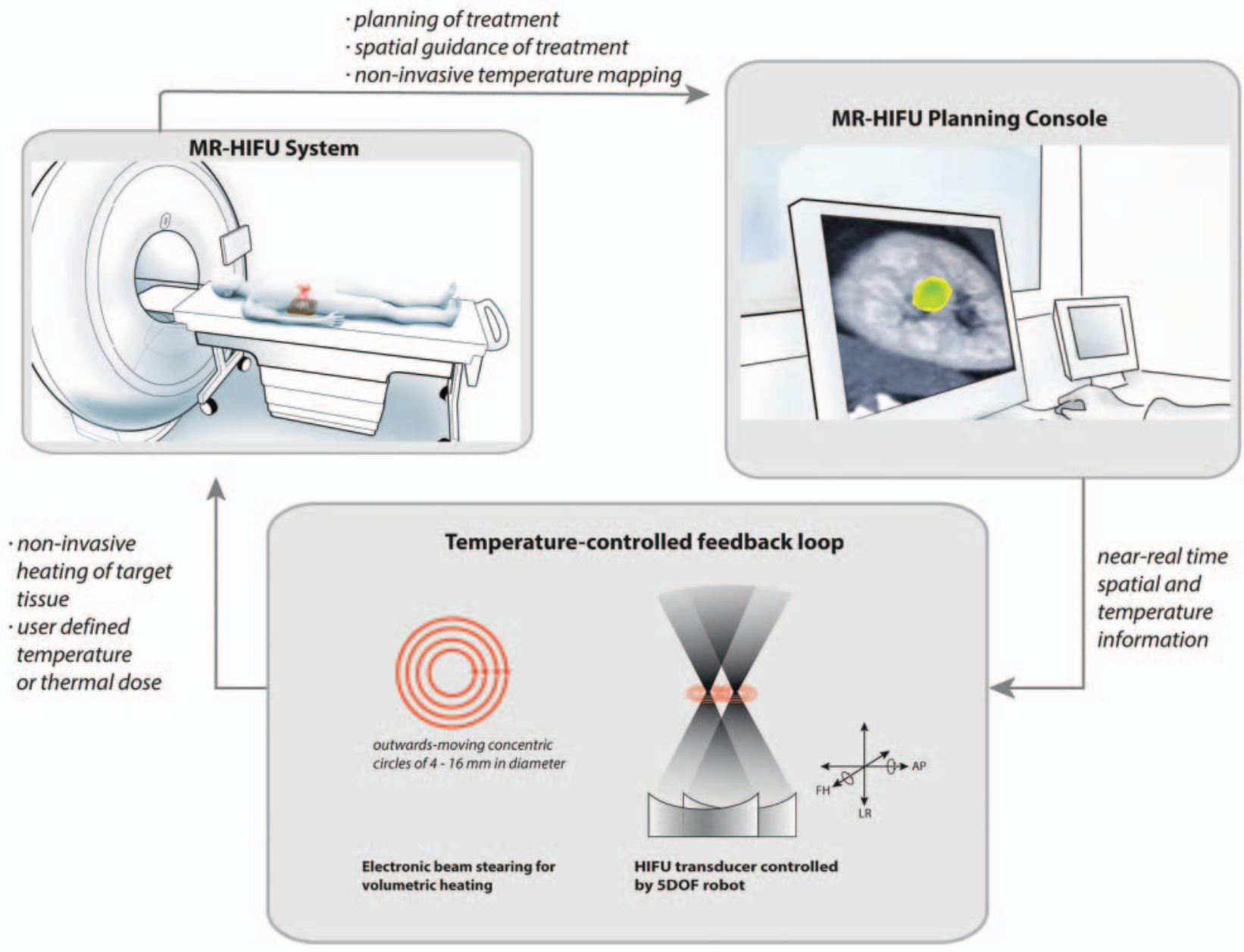

- Fig. 1 Schematic overview of an MR-HIFU system. MR guidance offers the possibility for procedure planning based on high contrast soft-tissue images, near real-time MR-thermometry for therapy control, and subsequent treatment assessment based on contrast-enhanced T1 scans. The latter is used to calculate the NPV after thermal ablation of tissues. MR-thermometry provides near real-time temperature maps which allow a feedback loop to the HIFU transducer to ensure deposition of a well-defined thermal dose in the target tissue, or to maintain prolonged hyperthermia at a constant temperature. The responsible radiologist has access to all anatomical images as well as superimposed temperature maps and can plan each sonication through the Planning Console which embeds sophisticated software for optimal energy disposition. Differently sized tissue volumes can be heated using electronic beam steering, and even larger volumes can be reached by displacing or tilting the transducer with the help of a motion robot. Source: Hijnen N, Langereis S, Grüll H. Magnetic resonance guided high-intensity focused ultrasound for image-guided temperature-induced drug delivery. Adv Drug Deliv Rev 2014; 72: 65 - 81 [rerif].

- Abb.1 Schematischer Überblick über ein MR-HIFU-System. Die Steuerung des HIFU-Systems mittels MRT ermöglicht die Therapieplanung anhand von Bildern mit hohem Weichteilkontrast, schafft die Therapiekontrolle mittels MR-Thermometrie in nahezu Echtzeit und erlaubt schlussendlich mithilfe einer KM-unterstützten T1-gewichteten Sequenz, Aussagen über den Therapieerfolg zu machen. Diese Sequenz wird auch zur Berechnung des NPV nach Thermoablation des Gewebes verwendet. Die MR-Thermometrie liefert nahezu Echtzeit-Temperaturkarten mit Rückkopplung zum HIFU-Transducer, um sicherzustellen, dass die thermale Dosis im Zielgewebe erreicht wurde, alternativ um eine prolongierte Hyperthermie mit einer konstanten Temperatur aufrechtzuerhalten. Der verantwortliche Radiologe kann auf alle anatomischen Bilder sowie die überlagerten Thermometrie-Daten zugreifen und anhand dieser jede Sonikation an der Planungskonsole mit der speziellen HIFU-Software planen, um eine optimale Energiedisposition zu erreichen. Unterschiedlich große Gewebsvolumina können erhitzt werden mittels Steuerung des Fokuspunktes; größere Volumina können abladiert werden, indem der Transducer mithilfe eines Bewegungsroboters verschoben bzw. abgekippt wird. Quelle: Hijnen N, Langereis S, Grüll H. Magnetic resonance guided high-intensity focused ultrasound for image-guided temperature-induced drug delivery. Adv Drug Deliv Rev 2014; 72: 65 - 81 [rerif].

posterior wall or near the Os sacrum count as relative contraindications [13]. When patients have the wish to become pregnant, myomectomy should be the first choice. However, this does not count as a contraindication for HIFU therapy as previous documented cases (>120) report pregnancies after HIFU, but patients need to be informed about possible complications and pregnancy should not be attempted for 6 months after therapy [13].

Many studies confirm MR-HIFU as a safe, feasible and effective alternative treatment option for myomas [8, 14-16]. Also, from an economic healthcare point of view, MR-HIFU may reduce the 
- Table 1 Overview of currently most relevant applications for MR-HIFU and US-HIFU depending on their status of approval worldwide adapted from an overview of approved applications from the Focused Ultrasound Foundation (https://www.fusfoundation.org/diseases-and-conditions-all/ overview).

- Tab. 1 Überblick über die derzeitig relevantesten Applikationen von MR-HIFU und US-HIFU in Abhängigkeit ihres Status der Zulassung adapiert von einer Übersicht zugelassener Applikationen der Focused Ultrasound Foundation (https://www.fusfoundation.org/diseases-and-conditions-all/ overview).

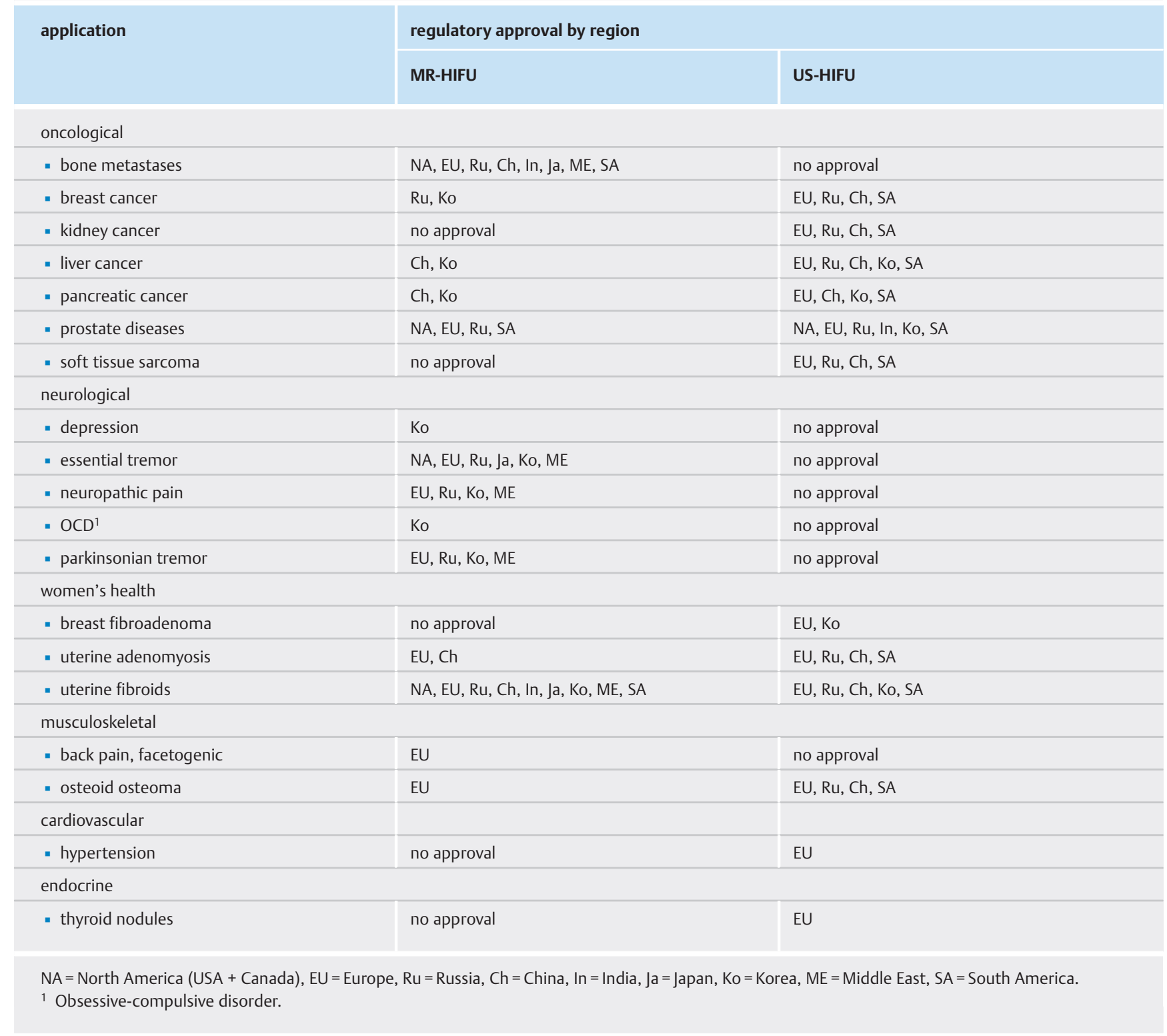

overall treatment costs and disease management thanks to fewer complications, shorter hospitalization and accelerated rehabilitation rates [17].

Complications may include pain, temporary vaginal discharge of necrotic material, cramps, skin burns and rarely nerve lesions [13].

\section{Bone-related applications}

Bone is the most common target site for the formation of distant metastases, which eventually occur in $70-80 \%$ of all patients suffering from solid tumors such as breast, lung and prostate cancer [18]. Bone metastases are often associated with strong pain and can lead to pathological fractures. At this stage, the disease is virtually incurable with a limited life expectancy, reduced mobility and strongly reduced quality of life. Treatment options in the management of bone metastases are palliative and directed at alleviating pain and comprise systemic therapies such as chemotherapy, hormonal therapy and bone-seeking bisphosphonates, as well as local treatments such as surgery, radiation therapy and thermal ablation using radiofrequency (RFA) or HIFU [19-21]. Radiotherapy, which is the current standard of care for the local treatment of painful metastases, achieves a response rate in $2 / 3$ of all patients within $2-8$ weeks, but in $1 / 4$ of treated patients pain even- 

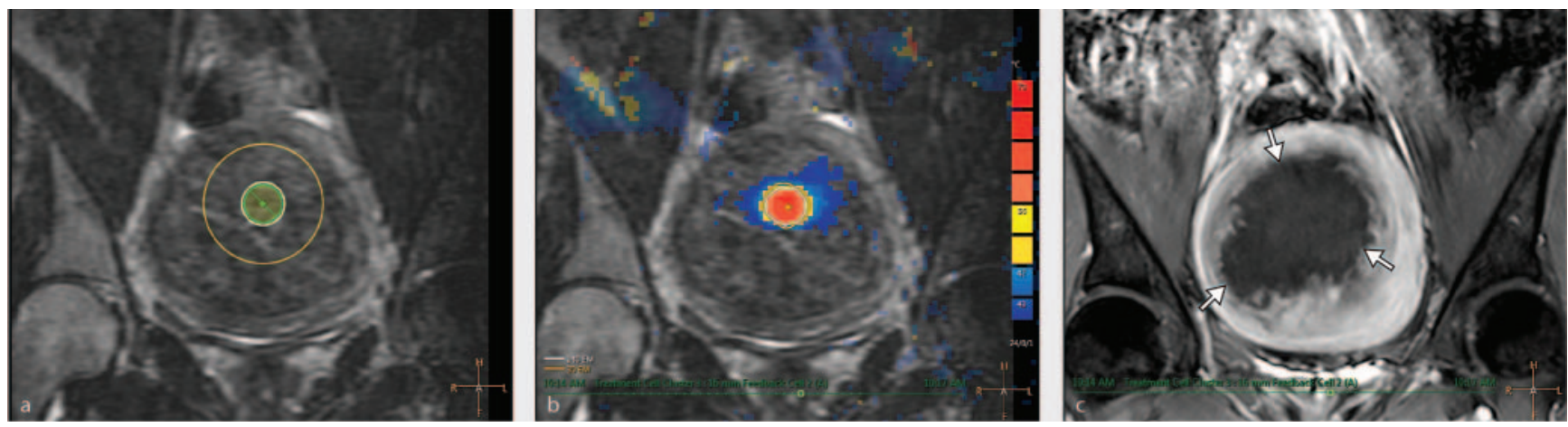

- Fig. 2 Representative MR images obtained during HIFU treatment of a uterine fibroid (Sonalleve, Profound Medical, Mississauga, Canada). a T2-weighted planning image (coronal view) with a representative treatment cell (green circle) placed in the center of a uterine fibroid; b MR-thermometry map obtained in a coronal slide at a depth of the treatment cell overlaid on the respective anatomical image; $\mathbf{c}$ contrast-enhanced T1-weighted image showing successfully ablated tissue as a hypointense area in the fibroid due to lack of perfusion (arrows). The ratio of total fibroid volume and non-perfused volume (NPV) is a measure for ablation efficacy.

- Abb.2 Repräsentative MR-Bilder während einer HIFU-Therapie eines Uterusmyoms (Sonalleve, Profound Medical, Mississauga, Canada). a T2-gewichtetes Planungsbild (koronare Darstellung) mit einer charakteristischen Therapiezelle (grüner Kreis), die im Zentrum eines Uterusmyoms platziert wurde; b MR-Temperaturkarte in koronarer Darstellung im Bereich der Therapiezelle überlagert mit einem entsprechenden anatomischen Bild; c Bild einer KM-unterstützten T1-gewichteten Sequenz, welches die erfolgreiche Gewebsablation als hypointenses Areal innerhalb des Myoms aufgrund ausbleibender Perfusion zeigt (Pfeile). Das Verhältnis vom Gesamtvolumen des Myoms und des nicht perfundierten Volumens (NPV) gilt als Maß für die Ablationseffizienz.

tually recurs after radiotherapy $[22,23]$. Retreatment with radiotherapy has a reduced response rate of about $60 \%$ and is limited by radiation dose. The mechanisms of pain relief after radiation therapy of bone metastases, however, are poorly understood [24]. As an alternative, thermal treatments aim at denervation of the highly sensitive periosteum to interrupt pain signaling [25]. HIFU has been used for pain palliation of bone metastases with a promising outcome [26, 27]. As the bone cortex absorbs about 50 times more ultrasound energy than soft tissue, lower acoustic powers are sufficient to adequately heat the bone surface and cause periosteal denervation [28]. Furthermore, as HIFU does not involve ionizing radiation and is virtually free of side effects, treatment can be repeated if needed.

MR-HIFU treatment protocols depend on the specific lesion morphology. In case an intact cortical bone surface is present, the high absorption of ultrasound in bone causes rapid heating even at moderate ultrasound energy exposures. The latter acts as a secondary heat source which causes local ablation of the periosteum adjacent to the bone. A commonly accepted treatment protocol for these lesions is the near-field approach, where the focus spot of HIFU is placed behind the cortical surface [29]. However, the effect of the interplay between sonication power and length of sonication on the ablation of soft tissue in front of the bone surface as well as the reached ablation depth within the bone is still under discussion [30]. As MR thermometry based on proton resonance frequency shift (PRFS) does not allow direct temperature mapping within the bone, heating of the adjacent soft tissue is commonly monitored as a secondary readout for successful heating of the bone surface ( $\mathbf{F i g}$. 3a, b). The treatment strategy for osteolytic lesions depends on the residual bone tissue left in the tumor lesion. The near-field approach may not lead to sufficient heating to achieve pain relief. Instead, the focus spot should be directed at the tumor mass eroding the bone to achieve soft tissue tumor ablation besides pain relief.

A phase 3 randomized trial including 112 patients showed pain relief with average onset three days after MR-HIFU treatment with a response rate of $64.3 \%$ compared to $20 \%$ in the placebo group [31]. Pain relief after HIFU treatment was long lasting, i. e., up to six months and longer. Furthermore, $27 \%$ of all responding patients could completely discontinue pain medication, while an additional $17 \%$ required less medication. Another prospective, single-arm research study including 18 patients examined pain relief from MR-HIFU in a first-line treatment setting. Here, $72.7 \%$ of all patients reported complete pain relief while omitting all pain medication and $16.7 \%$ of all patients reported partial pain relief while keeping pain medication constant. Remarkably, local tumor control was observed after MR-HIFU treatment in about $33.3 \%$ of all patients with restoration of bone integrity [32]. The clinical outcome of pain relief is supported by current preclinical studies pointing at thermal denervation of the bone and periosteum as the most prominent mechanism for pain relief [25]. Despite thermal ablation of the bone itself, there is no indication in clinical and preclinical studies that HIFU treatment could lead to an additional reduction of mechanical stability of weight-bearing bones or increase the risk of fractures [33]. HIFU-related complications can be comprised of skin burns or intramuscular edema with consecutive reduced mobility of the affected extremity directly after treatment that usually resolves within days.

The bone application space has been broadened to include the treatment of benign bone lesions such as osteoid osteomas or sub-cortical desmoids [34-40]. In a recent study, Sharma et al. demonstrated that MR-HIFU ablation of osteoid osteomas yields a comparable clinical response to radiofrequency ablation with the added benefit of being free of incisions and ionizing radiation [40]. 

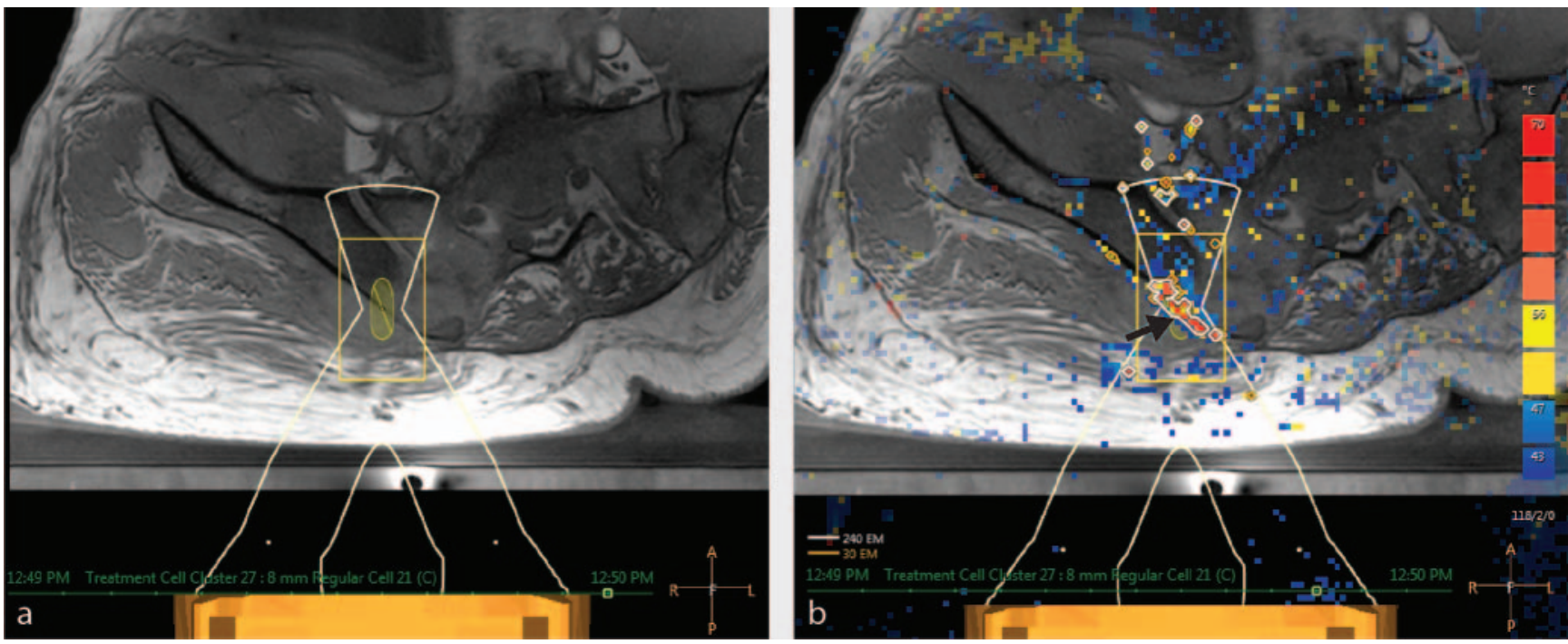

- Fig. 3 Treatment of an osteolytic bone lesion for pain palliation (Sonalleve, Profound Medical, Mississauga, Canada). a Treatment cell (yellow ellipsoid) placed on the cortical bone and soft tissue interface. $\mathbf{b}$ MR thermometry map showing temperature increase along the cortical surface and in the adjacent muscle (black arrow)

- Abb. 3 Therapie einer osteolytischen Knochenläsion zur Schmerzlinderung (Sonalleve, Profound Medical, Mississauga, Canada). a Therapiezelle (gelbe Ellipse), die auf die Kortikalis und die angrenzenden Weichteile platziert wurde. b MR-Thermometrie-Karte, die eine Temperaturzunahme entlang der kortikalen Oberfläche und den angrenzenden Muskel zeigt (schwarzer Pfeil).

Another interesting application is the treatment of pain related to facet joint arthritis [41], where HIFU offers a completely noninvasive alternative to standard treatments including minimally invasive RF ablation, medications (e.g., NSAIDs, topical analgesics), or local injections (e.g., steroids, analgesics).

\section{Neurological diseases}

Although the treatment of brain diseases was envisioned as one of the first clinical HIFU applications in the $1950 \mathrm{~s}$ [3], FDA approval for the treatment of essential tremor was first given in 2016 . While early HIFU studies required a craniotomy, a noninvasive therapy through the skull was finally made possible with a transducer covering the whole calvaria [42]. Corrections for scattering and refraction of ultrasound at the skull based on models derived from prior CT scans and using an improved HIFU transducer having 1024 beams (ExAblate Neuro, InSightec, Haifa, Israel) allow precise MR-guided focal ablation within the central part of the brain nowadays. To date, several non-oncological applications such as noninvasive ventriculostomy [43], thalamotomy to treat Parkinson's disease [44] and therapy for refractory neuropathic pain [45] have been described with first successes in clinical studies. A first study showed convincing results of a noninvasive cerebellothalamic tractotomy for the treatment of 21 patients with therapy-refractory essential tremor [46] and describes transcranial HIFU to be effective and safe. A randomized trial published by Elias et al. finally provided safety and efficacy data that led to the above-mentioned FDA approval of this method [47].

Ultrasound-induced cavitation in combination with intravenously administered microbubbles (i. e., ultrasound contrast agents) was also recognized for its potential to reversibly open the blood brain barrier [48]. That effect allows molecules to extra- vasate into the brain tissue that would normally be confined to the vascular system, though extent and time span depend on the size of the molecule and ultrasound parameters [49]. The approach was preclinically applied to improve drug delivery to brain cancer and also to treat neurological disorders such as Alzheimer disease. Recently, Lipsman et al. were able to demonstrate the safety and feasibility of opening the blood-brain barrier using MR-HIFU in a phase I safety trial which included five patients with Alzheimer's disease [50].

\section{Conclusion}

Currently, the clinical use of MR-HIFU is restricted to the thermal ablation of tissues and is well established for the treatment of uterine fibroids and for pain alleviation in patients suffering from bone metastases. For the treatment of uterine fibroids, MR-HIFU has been shown to be a patient-friendly, safe and effective therapeutic option, with reduced overall healthcare spending thanks to fewer complications, shorter hospitalization and accelerated rehabilitation rates. The use of MR-HIFU for pain palliation caused by bone metastasis offers the advantage of fast treatment response and the possibility for repeated treatment as HIFU does not involve ionizing radiation. Local tumor control after HIFU treatment has been reported in a few cases using MR-HIFU for firstline treatment but needs broader statistical evidence. As a first application in neurological disorders, MR-HIFU recently gained approval for the treatment of essential tremor. Other neurological applications are currently being investigated. 


\section{Conflict of Interest}

The authors declare that they have no conflict of interest.

\section{References}

[1] Wood RW, Loomis AL. The physical and biological effects of high-frequency sound-waves of great intensity. Philos Mag 1927; 4: 417-436

[2] Lynn JG, Zwemer RL, Chick AJ et al. A New Method for the Generation and Use of Focused Ultrasound in Experimental Biology. J Gen Physiol 1942; 26: 179-193

[3] Fry W], Barnard JW, Fry EF et al. Ultrasonic lesions in the mammalian central nervous system. Science 1955; 122: 517- 518

[4] Hynynen K, Damianou C, Darkazanli A et al. The feasibility of using MRI to monitor and guide noninvasive ultrasound surgery. Ultrasound Med Biol 1993; 19: $91-92$

[5] Shaw A, ter Haar G. Requirements for Measurement Standards in HIFU Fields. NPL Report DQL AC015. National Physics Laboratory 2006

[6] Whittingham TA. The acoustic output of diagnostic machines. In: ter Haar G, Duck FA, eds.; The safe use of ultrasound in medical diagnosis. London, UK: British Medical Ultrasound Society/British Insitute of Radiology; 2000: 16-31

[7] Köhler MO, Mougenot C, Quesson B et al. Volumetric HIFU ablation under 3D guidance of rapid MRI thermometry. Medical Physics 2009: $3521-3535$

[8] Quinn SD, Gedroyc WM. Thermal ablative treatment of uterine fibroids. Int J Hyperthermia 2015; 31: 272-279

[9] Trumm CG, Stahl R, Clevert DA et al. Magnetic resonance imaging-guided focused ultrasound treatment of symptomatic uterine fibroids: impact of technology advancement on ablation volumes in 115 patients. Invest Radiol 2013; 48: 359-365

[10] Park M], Kim YS, Rhim H et al. Safety and therapeutic efficacy of complete or near-complete ablation of symptomatic uterine fibroid tumors by MR imaging-guided high- intensity focused US therapy. J Vasc Interv Radiol 2014; 25: $231-239$

[11] Funaki K, Fukunishi H, Funaki T et al. Magnetic resonance-guided focused ultrasound surgery for uterine fibroids: relationship between the therapeutic effects and signal intensity of preexisting T2-weighted magnetic resonance images. Am J Obstet Gynecol 2007; 196: 184. e1 -6

[12] Yeo SY, Kim Y, Lim HK et al. Uterine fibroids: Influence of "T2-Rim sign" on immediate therapeutic responses to magnetic resonance imagingguided high-intensity focused ultrasound ablation. Eur J Radiol 2017; 97: $21-30$

[13] David M, Matzko M. MR-Guided Focused Ultrasound in Fibroid Treatment - Results of the 3rd Radiological-Gynecological Expert Meeting. Fortschr Röntgenstr 2017; 189: 515-518

[14] Fröling V, Kröncke TJ, Schreiter NF et al. Technical eligibility for treatment of magnetic resonance-guided focused ultrasound surgery. Cardiovasc Intervent Radiol 2014; 37: 445-450

[15] Dobrotwir A, Pun E. Clinical 24 months experience of the first MRgFUS Unit for treatment of uterine fibroids in Australia. J Med Imaging Radiat Oncol 2012; 56: 409-416

[16] Ruhnke H, Eckey T, Bohlmann MK et al. MR-guided HIFU treatment of symptomatic uterine fibroids using novel feedback-regulated volumetric ablation: effectiveness and clinical practice. Fortschr Röntgenstr 2013; 184: $983-991$

[17] Babashov V, Palimaka S, Blackhouse G et al. Magnetic Resonance-Guided High-Intensity Focused Ultrasound (MRgHIFU) for Treatment of Symptomatic Uterine Fibroids: An Economic Analysis. Ont Health Technol Assess Ser 2015; 15: 1-61
[18] Coleman RE. Clinical features of metastatic bone disease and risk of skeletal morbidity. Clin Cancer Res 2006; 12: 6243s-6249s

[19] Ringe KI, Panzica M, von Falck C. Thermoablation of Bone Tumors. Fortschr Röntgenstr 2016; 188: 539-550

[20] Barile A, Arrigoni F, Zugaro L et al. Minimally invasive treatments of painful bone lesions: state of the art. Med Oncol 2017; 34: 53

[21] Liberman B, Gianfelice D, Inbar Y et al. Pain palliation in patients with bone metastases using MR-guided focused ultrasound surgery: a multicenter study. Ann Surg Oncol 2009; 16: 140-146

[22] Saarto $T$, Janes $R$, Tenhunen $M$ et al. Palliative radiotherapy in the treatment of skeletal metastases. Eur J Pain 2002; 6: 323-330

[23] Huisman M, Van Den Bosch MAAJ, Wijlemans JW et al. Effectiveness of reirradiation for painful bone metastases: a systematic review and metaanalysis. Int J Radiat Oncol Biol Phys 2012; 84: 8-14

[24] Maisano R, Pergolizzi S, Cascinu S. Novel therapeutic approaches to cancer patients with bone metastasis. Crit Rev Oncol Hematol 2001; 40: 239-250

[25] Yeo SY, Elevelt A, Donato K et al. Bone metastasis treatment using magnetic resonance-guided high intensity focused ultrasound. Bone 2015; 81: $513-523$

[26] Catane R, Beck A, Inbar Y et al. MR-guided focused ultrasound surgery (MRgFUS) for the palliation of pain in patients with bone metastases preliminary clinical experience. Ann Oncol 2007; 18: 163-167

[27] Gianfelice D, Gupta C, Kucharczyk W et al. Palliative treatment of painful bone metastases with MR imaging-guided focused ultrasound. Radiology 2008; 249: 355-363

[28] Ten Eikelder HMM, Bošnački D, Elevelt A et al. Modelling the temperature evolution of bone under high intensity focused ultrasound. Phys Med Biol 2016; 61: 1810-1828

[29] Huisman M, ter Haar G, Napoli A et al. International consensus on use of focused ultrasound for painful bone metastases: Current status and future directions. Int J Hyperthermia 2015; 31: 251-259

[30] Bucknor MD, Ozhinsky E, Shah R et al. Effect of Sonication Duration and Power on Ablation Depth During MR-Guided Focused Ultrasound of Bone. J Magnet Reson Imaging 2017; 46: 1418 - 1422

[31] Hurwitz MD, Ghanouni P, Kanaev SV et al. Magnetic resonance-guided focused ultrasound for patients with painful bone metastases: phase III trial results. J Natl Cancer Inst 2014; 106: 1 -9

[32] Napoli A, Anzidei M, Marincola BC et al. Primary pain palliation and loca tumor control in bone metastases treated with magnetic resonanceguided focused ultrasound. Invest Radiol 2013; 48: 351-358

[33] Yeo SY, Arias Moreno AJ, van Rietbergen B et al. Effects of magnetic resonance-guided high-intensity focused ultrasound ablation on bone mechanical properties and modeling. J Ther Ultrasound 2015; 3: 13

[34] Napoli A, Bazzocchi A, Scipione R et al. Noninvasive Therapy for Osteoid Osteoma: A Prospective Developmental Study with MR Imaging-guided High-Intensity Focused Ultrasound. Radiology 2017; 285: 186-196

[35] Masciocchi C, Zugaro L, Arrigoni F et al. Radiofrequency ablation versus magnetic resonance guided focused ultrasound surgery for minimally invasive treatment of osteoid osteoma: a propensity score matching study. Eur Radiol 2016; 26: 2472-2481

[36] Rovella MS, Martins GL, Cavalcanti CF et al. Magnetic Resonance-Guided High-Intensity Focused Ultrasound Ablation of Osteoid Osteoma: A Case Series Report. Ultrasound Med Biol 2016; 42: 919-923

[37] Arrigoni F, Barile A, Zugaro L et al. Intra-articular benign bone lesions treated with Magnetic Resonance-guided Focused Ultrasound (MRgFUS): imaging follow-up and clinical results. Med Oncol 2017; 34: 55

[38] Geiger D, Napoli A, Conchiglia A et al. MR-guided focused ultrasound (MRgFUS) ablation for the treatment of nonspinal osteoid osteoma: a prospective multicenter evaluation. J Bone Joint Surg Am 2014; 96: $743-751$ 
[39] Yarmolenko PS, Eranki A, Partanen A et al. Technical aspects of osteoid osteoma ablation in children using MR-guided high intensity focussed ultrasound. Int J Hyperthermia 2017; 24: 1 -10

[40] Sharma KV, Yarmolenko PS, Celik H et al. Comparison of Noninvasive High-Intensity Focused Ultrasound with Radiofrequency Ablation of Osteoid Osteoma. J Pediatr 2017; 190: 222 -228.e1

[41] Weeks EM, Platt MW, Gedroyc W. MRI-guided focused ultrasound (MRgFUS) to treat facet joint osteoarthritis low back pain - case series of an innovative new technique. Eur Radiol 2012; 22: 2822 - 2835

[42] Hynynen K, McDannold N, Clement G et al. Pre-clinical testing of a phased array ultrasound system for MRI-guided noninvasive surgery of the brain - a primate study. Eur J Radiol 2006; 59: 149-156

[43] Alkins R, Huang Y, Pajek D et al. Cavitation-based third ventriculostomy using MRI-guided focused ultrasound. J Neurosurg 2013; 119: 1520 1529

[44] Elias W], Huss D, Voss T et al. A pilot study of focused ultrasound thalamotomy for essential tremor. N Engl J Med 2013; 369: 640-648
[45] Jeanmonod D, Werner B, Morel A et al. Transcranial magnetic resonance imaging-guided focused ultrasound: noninvasive central lateral thalamotomy for chronic neuropathic pain. Neurosurg Focus 2012; 32: E1

[46] Gallay MN, Moser D, Rossi F. Incisionless transcranial MR-guided focused ultrasound in essential tremor: cerebellothalamic tractotomy. J Ther Ultrasound 2016; 4: 5

[47] Elias W], Lipsman N, Ondo WG et al. A Randomized Trial of Focused Ultrasound Thalamotomy for Essential Tremor. N Engl J Med 2016; 375: $730-739$

[48] Hynynen K, McDannold N, Vykhodtseva N et al. Noninvasive MR imagingguided focal opening of the blood-brain barrier in rabbits. Radiology 2001; 220: 640-646

[49] Marty B, Larrat B, Van Landeghem M et al. Dynamic study of blood-brain barrier closure after its disruption using ultrasound: a quantitative analysis. J Cereb Blood Flow Metab 2012; 32: 1948 - 1958

[50] Lipsman N, Meng Y, Bethune A] et al. Blood-brain barrier opening in Alzheimer's disease using MR-guided focused ultrasound. Nat Commun 2018; 9: 2336 